\title{
Plant- Parasitic Nematodes Associated with Different Plants Grown in Newly Reclaimed Area in North West Egypt
}

\author{
A.M. Korayem, M.M.A. Youssef, M.M.M. Mohamed and A.M.S. Lashein \\ Plant Pathology Department, Nematology Laboratory, National Research Centre, Dokki, Post Code 12622 \\ Cairo, Egypt.
}

\begin{abstract}
A survey was conducted in $2014 / 2015$ to study distribution of plant parasitic nematodes associated with the different vegetables, field crops, fruit trees, weeds and some ornamental plants grown in Borg El-Arab and Amryia counties (sugar beet district), North West Egypt. Data indicated that twelve nematode genera and species were found at various percentages frequencies of occurrence and population densities according to host type and locality. The most predominant nematode genera were root-knot, Meloidogyne; stunt, Tylenchorhynchus; spiral, Helicotylenchus and reniform nematodes, Rotylenchulus reniformis as they were recovered at the highest percentages frequencies of occurrence and population densities.
\end{abstract}

Key words: Plant- parasitic nematodes, vegetables, field crops, fruit tree.

\section{Introduction}

In Egypt, phytoparasitic nematodes play an important role negatively influencing the productivity of important agricultural crops. Previous studies in Egypt have clarified that about 54 genera and 160 species of phytoparasitic nematodes were associated with many cultivated crops (Ibrahim, 1990; Ibrahim et al., 1994 and 2000; Heikal, 2001; Ibrahim and El-Sharkawy, 2001; El-Samra et al., 2005; Mokbel et al., 2006; Montasser et al., 2015 and Korayem et al., 2011). Also, the continuous cropping system and planting plants susceptible to plant parasitic nematodes stimulate rapid reproduction and development of such nematodes on different cultivated crops. The purpose of this research is to provide an accurate record on the occurrence and distribution of plant-parasitic nematodes associated with different vegetables, field crops and fruit trees grown in Borg El-Arab and Amryia, Alexandria governorate, Egypt.

\section{Material and Methods}

\section{Collection of soil and root samples:}

A total of 214 soil samples were randomly collected during 2014/2015 from the surveyed villages (no.1, 3, 4, 7) and some special companies in sugar beet region of sandy loam soil located in Amryia and Borg El-Arab counties, Alexandria governorate, North West Egypt. These samples were taken from the rhizosphere of vegetables and field plants besides some weed plants at a depth of $30-\mathrm{cm}$ by 
auger. For fruit trees, samples were taken at a depth of 40-60 cm under the canopy of the tree. Each sample was kept in polyethylene bag and sent directly to the laboratory for nematode extraction and identification.

\section{Extraction of nematodes from soil:}

Nematodes in soil were extracted in an aliquot of $200 \mathrm{~g}$ soil by sieving and decanting method (Byrd et al., 1996). The extracted nematodes were counted on Hawksly slide and identified under light microscope.

\section{Nematode identification:}

The surveyed nematodes were identified to generic level based on the morphology of adult and larval forms according to Golden (1971) and Mai and Lyon (1975).

\section{Nematode estimation:}

Population density (PD) (Mean no. of a given genus or species in each village) and frequency of occurrence \% (FO) (No. of soil samples containing a given genus or species/no. of whole samples collected X100) were calculated for each nematode genus or species.

\section{Results and Discussion}

Results in Table 1 indicate the presence of certain plant parasitic nematodes associated with the different annual plants and trees in region of sugar beet, Alexandria governorate. The surveyed samples contained 12 nematode genera as follows: Criconemoides, Ditylenchus, Helicotylenchus, Heterodera, Hoplolaimus, Meloidogyne, Pratylenchus, Rotylenchulus, Tylenchorhynchus, Tylenchulus, Xiphinema and Tylenchus. Of these genera, two were identified as Tylenchulus semipenetrans and Rotylenchulus reniformis. It was noticed that nematode population densities differed with location and host type as follows: The highest population density (2700 individuals $/ 200 \mathrm{~g}$ soil) of Meloidogyne was found on tomato in village no. 1 followed by Rotylenchulus reniformis (1200 individuals) on eggplant in village no.7 and Helicotylenchus. (873) on reed in village 3 . While the highest population density (295) of Pratylenchus was found on mallow in village no. 1 and its lowest population density (12) was found on sugar beet in village no.7. The highest population density (133) of Heterodera was found on potato in village no.1, while its lowest population density was found on maize in village no.4. 
Table (1): Population densities of phytoparasitic nematodes and associated host plants in some localities and villages of sugar beet region.

\begin{tabular}{|c|c|c|c|}
\hline $\begin{array}{l}\text { Name/ number } \\
\text { of villages and } \\
\text { companies }\end{array}$ & Host plant & Nematode genera & $\begin{array}{l}\text { Population } \\
\text { density in } \\
200 \mathrm{~g} \text { soil }\end{array}$ \\
\hline Village no. 1 & $\begin{array}{l}\text { Grapes: } \\
\text { (Vitis vinifera L.) }\end{array}$ & $\begin{array}{l}\text { Ditylenchus } \\
\text { Meloidogyne } \\
\text { Criconemoides } \\
\text { Rotylenchulus reniformis }\end{array}$ & $\begin{array}{r}12 \\
795 \\
119 \\
9 \\
\end{array}$ \\
\hline Village no. 1 & $\begin{array}{l}\text { Maize: } \\
\text { (Zea Mays L.) }\end{array}$ & $\begin{array}{l}\text { Rotylenchulus reniformis } \\
\text { Meloidogyne. }\end{array}$ & $\begin{array}{r}15 \\
300 \\
\end{array}$ \\
\hline Village no. 1 & $\begin{array}{l}\text { Tomato: } \\
\text { (Lycopersicon esculentum L.) }\end{array}$ & $\begin{array}{l}\text { Ditylenchus } \\
\text { Meloidogyne }\end{array}$ & $\begin{array}{r}9 \\
2700\end{array}$ \\
\hline Village no. 1 & $\begin{array}{l}\text { Date palm : } \\
\text { (Phoenix dactylifera L.) }\end{array}$ & $\begin{array}{l}\text { Meloidogyne } \\
\text { Rotylenchulus reniformis }\end{array}$ & $\begin{array}{r}118 \\
21 \\
\end{array}$ \\
\hline Village no. 1 & $\begin{array}{l}\text { Apricot: } \\
\text { (Prunus armeniaca L.) }\end{array}$ & Ditylenchus & 10 \\
\hline Village no. 1 & $\begin{array}{l}\text { Casuarina: } \\
\text { (Casuarina sp.) }\end{array}$ & $\begin{array}{l}\text { Meloidogyne. } \\
\text { Tylenchorhynchus. }\end{array}$ & $\begin{array}{l}13 \\
52\end{array}$ \\
\hline Village no. 1 & $\begin{array}{l}\text { Navel orange : } \\
\text { (Citrus sinensis L.) }\end{array}$ & Tylenchulus semipenetrans & 225 \\
\hline Village no. 1 & $\begin{array}{l}\text { Mandarin : } \\
\text { (Citrus nobilis L.) }\end{array}$ & Tylenchulus semipenetrans & 150 \\
\hline Village no. 1 & $\begin{array}{l}\text { Olives : } \\
\text { (Olea europaea L.) }\end{array}$ & $\begin{array}{l}\text { Ditylenchus. } \\
\text { Helicontylenchus } \\
\text { Meloidogyne. }\end{array}$ & $\begin{array}{l}58 \\
30 \\
55\end{array}$ \\
\hline Village no. 1 & $\begin{array}{l}\text { Potato: } \\
\text { (Solanum tuberosum L.) }\end{array}$ & $\begin{array}{l}\text { Ditylenchus } \\
\text { Heterodera } \\
\text { Pratylenchus } \\
\text { Rotylenchulus reniformis }\end{array}$ & $\begin{array}{r}16 \\
133 \\
161 \\
12 \\
\end{array}$ \\
\hline Village no. 1 & $\begin{array}{l}\text { Pear: } \\
\text { (Purus communis L.) }\end{array}$ & $\begin{array}{l}\text { Meloidogyne. } \\
\text { Pratylenchus. } \\
\text { Tylenchorhynchus }\end{array}$ & $\begin{array}{r}27 \\
102 \\
117 \\
\end{array}$ \\
\hline $\begin{array}{l}\text { Village no. } 3 \\
\text { (Sharka farm) }\end{array}$ & $\begin{array}{l}\text { Sugar beet: } \\
\text { (Beta vulgaris L.) }\end{array}$ & $\begin{array}{l}\text { Meloidogyne } \\
\text { Tylenchorhynchus }\end{array}$ & $\begin{array}{c}47 \\
543\end{array}$ \\
\hline $\begin{array}{l}\text { Village no. } 3 \\
\text { (Sharka farm) }\end{array}$ & $\begin{array}{l}\text { Wheat: } \\
\text { (Triticum sativum L.) }\end{array}$ & $\begin{array}{l}\text { Heterodera } \\
\text { Tylenchorhynchus }\end{array}$ & $\begin{array}{r}12 \\
144 \\
\end{array}$ \\
\hline $\begin{array}{l}\text { Village no. } 3 \\
\text { (Sharka farm) }\end{array}$ & $\begin{array}{l}\text { Reed : } \\
\text { (Phragmite sp.) }\end{array}$ & $\begin{array}{l}\text { Helicotylenchus } \\
\text { Hoplolaimus } \\
\text { Tylenchus. } \\
\text { Meloidogyne }\end{array}$ & $\begin{array}{r}873 \\
44 \\
30 \\
30 \\
\end{array}$ \\
\hline $\begin{array}{l}\text { Village no. } 3 \\
\text { Sharka farm)) }\end{array}$ & $\begin{array}{l}\text { Mallow: } \\
\text { (Malva parviflora L.) }\end{array}$ & $\begin{array}{l}\text { Pratylenchus. } \\
\text { Tylenchorhynchus }\end{array}$ & $\begin{array}{r}295 \\
33 \\
\end{array}$ \\
\hline Kodah land & $\begin{array}{l}\text { Wheat: } \\
\text { (Triticum sativum L.) }\end{array}$ & $\begin{array}{l}\text { Ditylenchus. } \\
\text { Helicontylenchus } \\
\text { Rotylenchulus reniformis } \\
\text { Tylenchorhynchus }\end{array}$ & $\begin{array}{c}54 \\
15 \\
15 \\
126\end{array}$ \\
\hline Kodah land & $\begin{array}{l}\text { Potato: } \\
\text { (Solanum tuberosum L.) }\end{array}$ & $\begin{array}{l}\text { Helicotylenchus } \\
\text { Meloidogyne } \\
\text { Tylenchorhynchus }\end{array}$ & $\begin{array}{l}42 \\
55 \\
25\end{array}$ \\
\hline Kodah land & $\begin{array}{l}\text { Watermelon: } \\
\text { (Citrulus vulgaris L.) }\end{array}$ & Tylenchorhynchus & 94 \\
\hline Kodah land & $\begin{array}{l}\text { Common dry bean: } \\
\text { (Phaseolus vulgaris L.) }\end{array}$ & $\begin{array}{l}\text { Helicotylenchus. } \\
\text { Heterodera } \\
\text { Pratylenchus }\end{array}$ & $\begin{array}{r}11 \\
17 \\
16 \\
\end{array}$ \\
\hline Teiba company & $\begin{array}{l}\text { Pepper: } \\
\text { (Capsicum frutescens L.) }\end{array}$ & $\begin{array}{l}\text { Ditylenchus. } \\
\text { Meloidogyne } \\
\text { Tylenchorhynchus } \\
\text { Tylenchus }\end{array}$ & $\begin{array}{l}12 \\
12 \\
41 \\
24\end{array}$ \\
\hline
\end{tabular}


Table 1.Continued:

\begin{tabular}{|c|c|c|c|}
\hline $\begin{array}{c}\text { Name/ number } \\
\text { of villages and } \\
\text { companies }\end{array}$ & Host plant & Nematode genera & $\begin{array}{l}\text { Population } \\
\text { density in } \\
200 \mathrm{~g} \text { soil }\end{array}$ \\
\hline \multirow[t]{2}{*}{ Matco company } & Valencia orange: & Ditylenchus & 19 \\
\hline & (Citrus sinensis L.) & Tylenchulus semipenetrans & 23 \\
\hline \multirow[t]{4}{*}{ Matco company } & Grapes: & Ditylenchus. & 25 \\
\hline & (Vitis Vinifera L.) & Helicotylenchus. & 53 \\
\hline & & Meloidogyne & 196 \\
\hline & & Tylenchus & 12 \\
\hline \multirow[t]{3}{*}{ Village no. 4} & Apple: & Pratylenchus. & 10 \\
\hline & (Pyrus malus L.) & Tylenchorhynchus & 20 \\
\hline & & Xiphinema & 34 \\
\hline \multirow[t]{2}{*}{ Village no. 4} & Wheat: & Pratylenchus & 30 \\
\hline & (Triticum sativum L.) & Tylenchorhynchus & 73 \\
\hline \multirow[t]{3}{*}{ Village no. 4} & Egyptian clover : & Heterodera. & 16 \\
\hline & (Trifolium alexandrinum L.) & Rotylenchulus reniformis & 25 \\
\hline & & Tylenchorhynchus & 64 \\
\hline Village no. 4 & $\begin{array}{l}\text { Tomato: } \\
\text { (Lycopersicon esculentum L.) }\end{array}$ & Tylenchorhynchus & 10 \\
\hline Village no. 4 & $\begin{array}{l}\text { Deadly nightshade: } \\
\text { (Atropa bellandonna L.) }\end{array}$ & Tylenchorhynchus & 70 \\
\hline Village no. 4 & $\begin{array}{l}\text { Elephant grass: } \\
\text { (Pennisetum purpurem Sch.) }\end{array}$ & $\begin{array}{l}\text { Tylenchorhynchus } \\
\text { Xiphinema }\end{array}$ & $\begin{array}{l}57 \\
20\end{array}$ \\
\hline Village no. 4 & $\begin{array}{l}\text { Squash: } \\
\text { (Cucurbita pepo L.) }\end{array}$ & Tylenchorhynchus & 36 \\
\hline \multirow[t]{5}{*}{ Village no. 4} & Maize: & Heterodera & 7 \\
\hline & (Zea Mays L.) & Pratylenchus & 29 \\
\hline & & Rotylenchulus reniformis & 8 \\
\hline & & Helicontylenchus & 20 \\
\hline & & Tylenchorhynchus & 30 \\
\hline Village no. 4 & $\begin{array}{l}\text { Pepper: } \\
\text { (Capsicum frutescens L. ) }\end{array}$ & Tylenchorhynchus & 30 \\
\hline \multirow[t]{3}{*}{ Village no. 4} & Banana: & Meloidogyne & 53 \\
\hline & (Musa sp.) & Tylenchorhynchus & 81 \\
\hline & & Xiphinema & 12 \\
\hline \multirow[t]{5}{*}{ Village no. 7} & Sugar cane: & Pratylenchus & 12 \\
\hline & (Saccharum officinarum L.) & Rotylenchulus reniformis & 163 \\
\hline & & Tylenchorhynchus & 9 \\
\hline & & Helicotylenchus & 288 \\
\hline & & Xiphinema & 9 \\
\hline \multirow[t]{4}{*}{ Village no. 7} & Egyptian clover: & Pratylenchus & 25 \\
\hline & (Trifolium alexandrinum L.) & Rotylenchulus reniformis & 132 \\
\hline & & Tylenchorhynchus & 189 \\
\hline & & Helicotylenchus & 38 \\
\hline \multirow[t]{5}{*}{ Village no. 7} & Sugar beet: & Meloidogyne & 14 \\
\hline & (Beta vulgaris L.) & Pratylenchus. & 290 \\
\hline & & Rotylenchulus reniformis & 26 \\
\hline & & Tylenchorhynchus & 295 \\
\hline & & Helicotylenchus & 69 \\
\hline
\end{tabular}


Table 1.Continued:

\begin{tabular}{|c|c|c|c|}
\hline $\begin{array}{c}\text { Name/ number } \\
\text { of villages and } \\
\text { companies }\end{array}$ & Host plant & Nematode genera & $\begin{array}{l}\text { Population } \\
\text { density in } \\
200 \mathrm{~g} \text { soil }\end{array}$ \\
\hline \multirow[t]{2}{*}{ Village no. 7} & Cabbage: & Pratylenchus & 14 \\
\hline & (Brassica oleracea L.) & Tylenchorhynchus & 284 \\
\hline \multirow[t]{5}{*}{ Village no. 7} & Eggplant: & Pratylenchus & 73 \\
\hline & (Solanum melongena L.) & Rotylenchulus reniformis & 1280 \\
\hline & & Tylenchorhynchus & 225 \\
\hline & & Helicotylenchus & 42 \\
\hline & & Meloidogyne & 290 \\
\hline \multirow[t]{2}{*}{ Village no. 7} & Pepper & Tylenchorhynchus & 169 \\
\hline & (Capsicum frutescens L.) & & \\
\hline \multirow[t]{3}{*}{ Village no. 7} & Lettuce: & Pratylenchus & 150 \\
\hline & (Lactuca sativa L.) & Rotylenchulus reniformis & 180 \\
\hline & & Tylenchorhynchus & 210 \\
\hline \multirow[t]{3}{*}{ Village no. 7} & Maize: & Helicotylenchus. & 565 \\
\hline & (Zea Mays L.) & Pratylenchus & 196 \\
\hline & & Tylenchorhynchus & 50 \\
\hline \multirow[t]{5}{*}{ Village no. 7} & Sunflower: & Ditylenchus & 8 \\
\hline & (Helianthus annus L.) & Pratylenchus & 36 \\
\hline & & Helicotylenchus & 235 \\
\hline & & Rotylenchulus reniformis & 14 \\
\hline & & Tylenchorhynchus & 176 \\
\hline \multirow[t]{4}{*}{ Village no. 7} & Artichoke: & Meloidogyne. & 633 \\
\hline & (Cynara scolymus L.) & Pratylenchus. & 132 \\
\hline & & Rotylenchulus reniformis & 206 \\
\hline & & Tylenchorhynchus & 178 \\
\hline
\end{tabular}

As for the averages of population density and percentage frequency of occurrence of the surveyed nematodes (Table 2), it was noticed that root knot nematode has the highest population density and percentage frequency of occurrence averages in villages no. 1 and 3 as its percentage frequency $(35.6 \%)$ with population density (68 individuals $/ 200 \mathrm{~g}$ soil) in village no. 1 and $12.7 \%$ with 18 individuals in village no.3. Stunt nematode (Tylenchorhynchus) recorded the highest percentage frequency of occurrence and population density averages in villages no.4 and 7 , as they were $61.7 \%$ with 7.5 individuals in village no.4 and $76.7 \%$ with 30.0 individuals in village no.7, respectively. 
As for general average population density and percentage occurrence of frequency (Table 2), it was found that stunt nematode (Tylenchorhynchus) has the highest general average percentage of occurrence followed by lesion nematode (Pratylenchus) and root knot nematode (Meloidogyne) as they were 40.6, 18.9 and $17.9 \%$, respectively. While root knot nematode has the highest general average population density (25.6 individuals/200g soil), whereas lance nematode (Hoplolaimus) has the lowest one (0.2).

Table (2) Population density (PD) and percentage frequency of occurrence (FO \%) averages and general average of phytoparasitic nematodes associated with the surveyed plants grown in sugarbeet district, Alexandria governorate.

\begin{tabular}{|c|c|c|c|c|c|c|c|c|c|c|}
\hline \multirow{4}{*}{$\begin{array}{l}\text { Nematode genera } \\
\text { and species }\end{array}$} & \multicolumn{10}{|c|}{ The surveyed villages } \\
\hline & 1 & & 3 & & 4 & & 7 & & \multirow{2}{*}{\multicolumn{2}{|c|}{$\begin{array}{l}\text { General } \\
\text { average }\end{array}$}} \\
\hline & \multicolumn{8}{|c|}{$\begin{array}{l}\text { Av. percentage frequency of occurrence(FO) } \\
\text { and av. population density(PO) }\end{array}$} & & \\
\hline & FO\% & PD & FO\% & PD & FO\% & PD & $\mathrm{FO} \%$ & PD & FO\% & PD \\
\hline Criconemoides & 6.3 & 2 & - & - & - & - & - & - & 1.6 & 0.5 \\
\hline Ditylenchus & 11.1 & 2 & 1.5 & 1.9 & - & - & 1.7 & 0.1 & 3.6 & 1 \\
\hline Helicotylenchus & 2.5 & 0.2 & 7.3 & 17 & 8.3 & 0.3 & 41.7 & 21 & 15 & 9.6 \\
\hline Heterodera & 6.3 & 2.3 & 1.8 & 0.5 & 6.7 & 0.4 & - & - & 3.7 & 0.8 \\
\hline Hoplolaimus. & - & - & 3.6 & 0.7 & - & - & - & - & 0.9 & 0.2 \\
\hline Meloidogyne & 35.6 & 68 & 12.7 & 18 & 3.3 & 0.9 & 18.3 & 15.6 & 17.5 & 25.6 \\
\hline Pratylenchus & 3.8 & 5 & 1.8 & 5.3 & 11.7 & 1.3 & 58.3 & 15.7 & 18.9 & 6.8 \\
\hline Rotylenchulus reniformis & 5.0 & 1 & 1.8 & 0.3 & 5 & 0.6 & 45 & 30.0 & 14.2 & 8.0 \\
\hline Tylenchorhynchus & 12.5 & 3 & 11.5 & 17 & 61.7 & 7.5 & 76.7 & 30.3 & 40.6 & 14.5 \\
\hline Tylenchulus semipenetrans & 11.3 & 6 & 1.8 & 0.4 & - & - & - & - & 3.3 & 1.6 \\
\hline Tylenchus. & - & - & 5.5 & 1.1 & - & - & - & - & 1.4 & 0.3 \\
\hline Xiphinema & - & - & - & - & 6.7 & 1.1 & 1.7 & 0.2 & 2.1 & 0.3 \\
\hline No. of samples & 59 & - & 50 & - & 55 & - & 50 & - & - & - \\
\hline
\end{tabular}

$\mathrm{PD}=$ Population density. $\mathrm{FO} \%=$ Percentage frequency of occurrence.

Av.=Average

In the present study, soil and root samples collected from the different surveyed villages of sugar beet region clarified the presence of 12 genera and species of plant parasitic nematodes. Some of which cause dangerous quantity and quality losses to various plants in Egypt (Ibrahim and El- Sharkawy, 2001). Root knot nematode (Meloidogyne spp.) acts as one of the most pathogenic nematode, as it distributes in the most Egyptian soils (Elgindi and Moussa, 1971; Abou ElNaga et al., 1985; Oteifa et al., 1997; Ibrahim et al., 2000 and Korayem et al., 2014). The recent studies clarified that root knot nematode causes a large losses in yield of vegetable and field crops depending on nematode population density 
infesting such plants and predominant abiotic and biotic conditions and type of host plant (Youssef and Korayem, 2008, Korayem et al., 2012 and 2015). Also, citrus nematode, Tylenchulus semipenetrans (Korayem and Hassabo, 2005) and reniform nematode, Rotylenchulus reniformis (Ibrahim, 2011) both are considered the most important nematodes which induce damage to their host plants. Cyst nematode genus (Heterodera.) found in the present surveyed sample is considered a pathogenic pest for many crops in Europe and other temperate regions (Webster, 1972). Although some researches in Egypt were carried out to study the relationship between this nematode and certain crops (Aboul- Eid and Ghroab, 1974, 1981), its economic importance and amount of damage are scientifically uncertain probably refer to that the predominant environmental conditions play an important role influencing its distribution and dissemination. Other genera of plant parasitic nematodes were found in the surveyed samples as ring nematode (Criconemoides), lance nematode (Hoplolaimus), stunt nematode (Tylenchorh-ynchus), and lesion nematode (Pratylenchus). Their economic importance and amount of damage have not received the required attention. Hence, more studies are needed to determine the amount of damage caused by these nematodes, susceptible or resistant plants and suitable abiotic and biotic conditions for their infection and survival. The stem and bulb nematode, Ditylenchus was found in the most samples. Some species belonging to this genus are known to be the main causes of dangerous diseases to potato in Europe and bulb plants and rice in south east of Asia as follows: $D$. destructor causes potato rot disease, $D$. dipsaci infects bulb plants and D. angusts infects rice stem (Ibrahim, 2010, Webster, 1972). There was no available scientific information on the existence of such species in Egypt which may be referred to the difference in abiotic and biotic conditions or may be explained on the basis that the predominant species in Egypt is $D$. myceliophora which feeds on soil fungi.

In brief, the collected soil samples from certain villages and companies in Borg El-Arab and Amryia clarified the distribution of plant parasitic nematodes under the predominant environmental conditions and soil types in the surveyed villages. This helps in developing appropriate necessary plans for managing these nematode pests by eco-friendly methods leading to an increase in an economic production and safe agricultural byproducts.

\section{References}

Aboul El-Naga, M.M., Mahros, M.E. and Montasser, S.A. (1985). A survey of nematodes associated with vegetable crops in Egypt. J. Agric. Res., Tanta Univ. 11, 547-553.

Aboul-Eid, H.Z. and Ghorab, A.I., (1974). Pathological effects of Heterodera cajani on cowpea. Plant Dis. Reptr. 58, 1130-1133. 
Aboul-Eid, H.Z. and Ghorab, A.I. (1981). The Occurrence of Heterodera zeae in maize fields in Egypt. Egypt. J. Phytopathol. 13, 51-61.

Byrd, D.W., Nusbaum, Jr. C.J. and Barker, K.R. (1996). A rapid Floatation sieving technique for extracting nematodes from soil. Plant Dis. Reptr. 50, 954-957.

Elgindi, D.M. and Moussa, F.F. 1971. Root- knot nematodes in recently reclaimed sandy areas of Egypt. II- New host records for root- knot nematode Meloidogyne spp. Meded. Fac. Landbouw. Rijks Univ. Gent, 36, 1341-1344.

El-Samra, I.A., El-Saedy, M.A., El-Farnawany, M.A. and Allam, A.F. (2005). Survey of plant-parasitic nematodes and phytopathogenic fungi associated with citrus trees in Egypt. J. Adv. Agric. Res., Fac. Agric., Saba Basha, Alexandria, 10, 979-996.

Golden, A.M. (1971). Classification of the genera and higher categories of the order Tylenchida (Nematoda). Pp: 191-232. In: B.M Zuckerman, W.F. Mai and R.A. Rohde (eds). Plant Parasitic Nematodes, 1. Morphology, Anatomy, Taxonomy, and Ecology, New York: Academic Press.

Heikal, H.M. (2001). Pathological and biological studies on parasitic nematodes affecting banana in Egypt. M.Sc. Thesis. Fac. of Agric., Damanhour, Alexandria Univ., Egypt.

Ibrahim, I.K.A. (1990). The status of phytoparasitic nematodes and the associated plants in Egypt. Intern. Nematol. Network Newsl. 7, 33-38.

Ibrahim, I.K.A., El-Saedy, M.A. and El-Sherbiny, A.A. (1994). Survey study of plant parasitic nematodes in Egypt. J. Nematol. 26, 553 (Abst.).

Ibrahim, I.K.A., Handoo, Z.A. and El-Sherbiny, A.A. (2000). A survey of phytoparasitic nematodes on cultivated and non- cultivated plants in north western Egypt. Suppl. to J. Nemotol. 32, 478-485.

Ibrahim, I.K.A. and El-Sharkawy, T.A. (2001). Genera and species of phytoparasitic nematodes and the associated host plants in Egypt. Adv. Agric. Res., Egypt. 3, 75-95.

Ibrahim, I.K.A. (2010). Nematode parasites of field and fruit crops: Pathology and control, (ed.). Manshaat El- Maaref Press, Alexandria. (In Aarbic), 369pp.

Ibrahim, I.K.A. (2011). Nematode parasites of field crops: Pathology and Control. Manshaat El- Maaref. Press, Alexandria (In Arabic), 250 pp.

Korayem, A.M. and Hasabo S.A.A. (2005). Citrus yield in relation to Tylenchulus semipenetrans in silty loam soil. Intern. J. Nematol. 15, 179-182. 
Korayem, A.M., Youssef, M.M.A., Ahmed, M.M. and Mohamed, M.M.M. (2011). Distribution and Association of plant - Parasitic Nematodes with some oil Crops in Egypt. Pak. J. Nematol. 29, 79-91.

Korayem, A.A., Mohamed, M.M.M. and Abou-Hussein, S.D. (2012). Damage threshold of root - knot nematode, Meloidogyne arenaria to potato grown in naturally and artificially infected field and its effect on some tubers properties. J. Appl. Sci. Res. 8, 1445-1452.

Korayem, A.M., Youssef, M.M.A., Mohamed, M.M.M. and Lashein, A.M.S. (2014). A Survey of plant parasitic nematodes associated with different plants in North Sinai. Middle East J. Agric. Res. 3, 522-529.

Korayem, A.M., Mohamed, M.M.M. and El-Ashry, S.M. (2015). Damage threshold of Melodiogyne arenaria to common bean influenced by dates of planting. Pak. J. Nematol. 33, 87-92.

Mai, W.F. and Lyon, H.H. (1975). Pictorial key to genera of plant - parasitic nematodes. Ithaca, NY: Cornell University Press.

Mokbel, A.A., Ibrahim, I.K.A., EL-Saedy, M.A.M. and Hammad, S.E., (2006). Plant Parasitic Nematodes associated with some fruit Trees and vegetable crops in Northern Egypt. Egypt. J. Phytopathol. 34, 43-51.

Montasser, S.A., Korayem, A.M., Youssef, M.M.A. and Mohamed, M.M.M. (2015). Vertical distribution of the root lesion nematode, Pratylenchus zeae infesting sugarcane in relation to soil type and growing season. Sci. Agric. 10, 95-97.

Oteifa, B.A., Shamseldeen, M.M. and El-Hamawi, M.H.(1997). A preliminary complied study on the biodiversity of free- living, plant and insect - parasitic nematodes in Egypt. Egypt. J. Agronematol. 1, 1-36.

Webster, J.M. (ed.) (1972). Economic Nematology. Academic Press, London. New York, 563pp.

Youssef, M.M.A. and Korayem, A.M. (2008). The relationship between eggplant yield and number of galls caused by Meloidogyne incognita and cellular alterations of the infested plants. Plant Prot. Bull. 50, 35-41, China. 


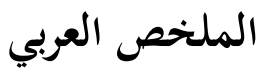

النيماتودا المصاحبة للنباتات النامية في الأراضي المستصحلة حديثًا

في شمال غرب جمهورية مصر العربية

أحمد محمد كريم، محمود محمد أحمد يوسف، معوض محمد محمد محمد، وأسمهان محمد شوقي

لاشين

قسم أمراض النبات والنيماتودا - المركز القومي للبحوث-الجيزة- مصر.

أجريت الدراسة لحصر أنواع النيماتودا المتطفلة علي النباتات في منطقة بنجر السكر الواقعة

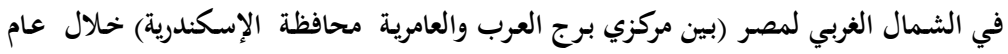

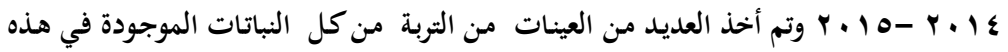

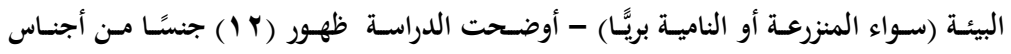

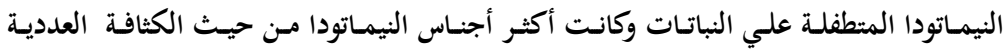

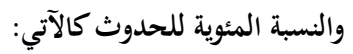

Genus: Meloidogyne نيماتودا تعقد الجذور

Genus: Tylenchorhynchus نيماتودا تقزم الجذور

Tenus: Helicotylenchus النيماتودا الحلزونية

Genus: Rotylenchulus reniformis النيماتودا الكلوية

بقية أجناس وأنواع النيماتودا ظهرت بنسب ظهور وكثافة قليلة. 